\title{
IMPERFECT EQUALITY
}




\section{Reconstructing America Series \\ Paul Cimbala, series editor}

1. Hans L. Trefousse, Impeachment of a President: Andrew Johnson, the Blacks, and Reconstruction. 


\title{
IMPERFECT EQUALITY
}

African Americans and the Confines of White Racial Attitudes in Post-Emancipation Maryland

\author{
Richard Paul Fuke
}

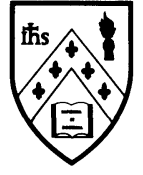

Fordham University Press

New York

1999 
Copyright (C) 1999 by Richard Paul Fuke

All rights reserved. No part of this publication may be reproduced, stored in a retrieval system, or transmitted in any form or by any means-electronic, mechanical, photocopy, recording, or any other-except for brief quotations in printed reviews, without the prior permission of the publisher.

Reconstructing America, no. 2

Library of Congress Cataloging-in-Publication Data

Fuke, Richard Paul, 1940-

Imperfect equality : African Americans and the confines of white racial attitudes in post-emancipation Maryland / Richard Paul Fuke.

p. cm.-(Reconstructing America; no. 2)

Includes bibliographical references and index.

ISBN 13: 978-0-8232-1963-6

1. Afro-Americans-Civil rights-Maryland-History-19th century.

2. Freedmen-Maryland-History. 3. Whites-Maryland-AttitudesHistory-19th century. 4. Reconstruction-Maryland. 5. MarylandRace relations. I. Title. II. Series: Reconstructing America (Series); no. 2.

E185.93.M2F85 1999

$305.896^{\prime} 0730752-\mathrm{dc} 21$

99-24308

CIP

Printed in the United States of America $\begin{array}{llllllllll}99 & 00 & 01 & 02 & 03 & 5 & 4 & 3 & 2 & 1\end{array}$ First Edition 
To Phebe Jacobsen 
